\title{
NINE ADDITIONAL CULTIVATED SPECIES OF ASTERACEAE FROM JAVA
}

\author{
Arifin Surya Dwipa Irsyam*1, Rina Ratnasih Irwanto ${ }^{2}$
}

Received : June 04, 2019

Accepted : November 03, 2019

DOI: $10.15575 /$ biodjati.v4i2.4815

${ }^{1}$ Herbarium Bandungense (FIPIA), School of Life Sciences and Technology (SITH), Institut Teknologi Bandung, Jl. Let. Jend. Purn. Dr. (HC) Mashudi No.1, Sayang, Jatinangor, Sumedang districts, West Java, Indonesia 45363 ${ }^{2}$ School of Life Sciences and Technology (SITH), Institut Teknologi Bandung, Jl. Ganesha No. 10, Bandung, West Java Indonesia 40132

e-mail:

*1arifin@sith.itb.ac.id

²rina@sith.itb.ac.id

*Corresponding author

\begin{abstract}
Asteraceae is one of the largest families in the Angiosperm. It comprises of 24,000-30,000 species which are grouped into 1,600-1,700 genera and distributed in a cosmopolitan range. Based on Backer and Bakhuizen van den Brink's 1965 works, they identified 227 species of Asteraceae in Java. Many of them are introduced species, both cultivated or naturalized. However, the cultivated species have not been recorded. The aim of this study was to provide information about new records of cultivated Asteraceae in Java. The observations were carried out in Bandung, Bogor and Sumedang, from January to March 2019. Nine additional species were discovered; species belonging to genera Caputia (two species), Curio (two species), Kleinia (one species), Gymnanthemum (one species), Senecio (two species) and Tarlmounia (one species). These species were grouped into two tribes: Vernonieae and Senecioneae. This study indicates that information on Asteraceae of Java needs to be updated.
\end{abstract}

Keywords: additional species, asteraceae, cultivated, Java

\section{Citation}

Irsyam, A. S. D. \& Iwanto, R. R. (2019). Nine Additional Cultivated Species of Asteraceae from Java. Jurnal Biodjati, 4(2), 244-251

\section{INTRODUCTION}

The sunflower family or Asteraceae consists of 24,000-30,000 species that are distributed around the globe, except for Antarctica. The Asteraceae family is one of the largest families in the Angiosperm (Funk et al., 2009). As many as 227 species of Asteraceae were discovered in the Java island, with 92 species among them introduced as ornamental plants. This includes Coreopsis grandiflora Hogg ex Sweet, Gerbera jamesonii Bolus ex Hook. f., Tagetes erecta L. and Zinnia elegans L. (Backer \& Bakhuizen v/d Brink, 1965). The cultivated species of Asteraceae contributes to a high number of Asteraceae diversity in Java. Flora of Java Vol 2 (Backer \& Bakhuizen v/d Brink, 1965) is still used as the main reference to the study on Asteraceae in Java during the present time. However, updating this book is strongly needed, due to some newly discovered species that have not been added yet. Furthermore, the classifications of some genera in this book have already been changed. For example, Eupatorium has been separated into Ageratina, Austroeupatorium, Ayapana, Bartlettina and Chromolaena (King \& Robinson, 1970a, 1970b, 1970c, 1970d; King \& Robinson, 1971). Besides, some newly recorded species were reported from 


\section{JURNAL BIDDJATI}

http://journal.uinsgd.ac.id/index.php/biodjati

Java in the last three years, such as Eupatorium capillifolium (Lam.) Small ex Porter \& Britton (Irsyam \& Hariri, 2016) and Praxelis clematidea (Griseb.) R.M.King \& H.Rob. (Tjitrosoedirdjo \& Wahyuni, 2018). Hence, the study aimed to provide information on other additional species of Asteraceae from Java Island.

\section{MATERIALS AND METHODS}

All of the plant materials used in this study were collected from nine urban localities in Bandung, Bogor and Sumedang, i.e. campus areas, traditional gardens, home gardens, and agritourism places. The field survey was conducted from January to March 2019. Plant materials were collected based on the exploration method (Rugayah et al., 2004). Data recorded includes collector name, collection number, morphological characters, vernacu- lar name, plant uses and location. Information on the use of species was obtained through a personal interview during the field survey. Plant materials were preserved and observed in Herbarium Bandungense (FIPIA), School of Life Sciences and Technology (SITH), Institut Teknologi Bandung (ITB).

\section{RESULTS AND DISCUSSION}

We found nine cultivated species of Asteraceae as new records in Java (Table 1). They were grouped into 6 genera, i.e. Caputia (2 species), Curio (2 species), Gymnanthemum (1 species), Kleinia (1 species), Senecio (2 species), and Tarlmounia (1 species). The species have not been recorded within the Flora of Java Vol. 2 (Backer \& Bakhuizen v/d Brink, 1965). The updated keys to the tribes and a key to the additional species are presented below:

An updated key to the Senecioneae of Java (modified from Backer \& Bakhuizen v/d Brink (1965))

1 A. Involucral bratcs ecalyculate Emilia

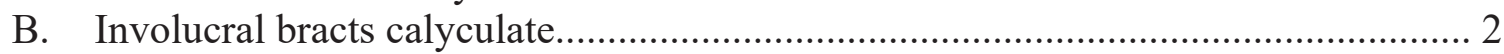

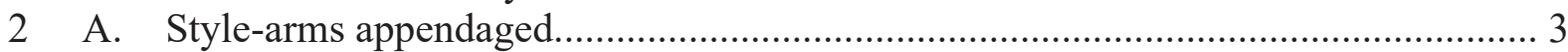

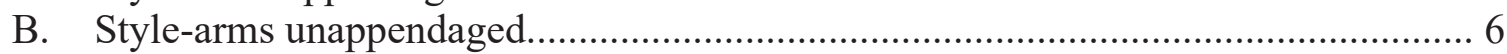

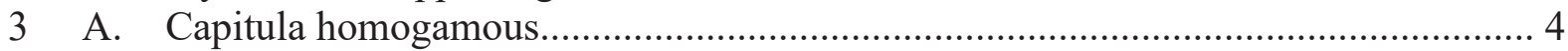

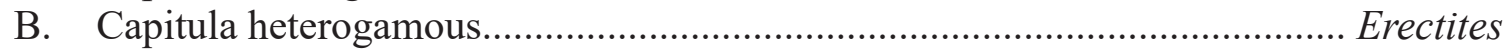

4 A. Leaves entire, glabrous................................................................................ Kleinia

B. Leaves lobed to partited, pubescens to glabrous................................................... 5

5 A. Corolla at the base rather abruptly widened, style arms tapering to the apex, hai

B. Corolla gradually widened into the limb, style arms with a truncate and subpenicillate apex. Crassocephalum

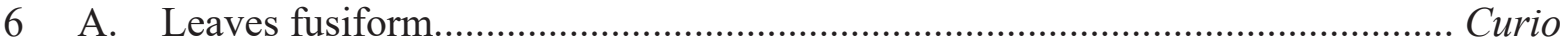

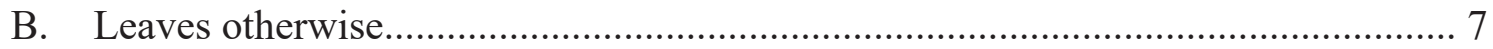

7 A. Capitula arranged in paniculate cyme, corymbiform cyme, or a simple panicle....... Roldana

B. Capitula arranged in corymbs or thyrses...................................................... 8

8 A. Capitula large, phyllaries $8-13$, achenes ellipsoid-oblong to fusiform-ellipsoid

B. Capitula small, phyllaries 5-22, achenes cylindric...................................... Senecio 


\section{JURNAL BIDDJATI}

http://journal.uinsgd.ac.id/index.php/biodjati

An updated key to the Vernonieae of Java (modified from Backer \& Bakhuizen v/d Brink (1965) and Ghafoor (2015))

1 A. Plants scrambling, capitula arranged in thyrsoid. Tarlmounia

B. Plants erect or suberect, capitula solitary, or arranged in clustered, spike, or corymb...

2 A. Pappus consisting of scales, or cup-shaped or wanting....................................... 3

B. Pappus consisting of numerous bristles............................................................... 5

3 A. Capitula large, c. $4 \mathrm{~cm}$ wide, outer involucral bracts foliaceous........................ Stokesia

B. Capitula rather or very small, outer involucral bracts not foliaceous.......................... 4

4 A. Capitula sessile, achenes curved, pappus cup-shape..................................... Struchium

B. Capitula shortly pedunculate, achenes obpyramidal, pappus wanting............... Ethulia

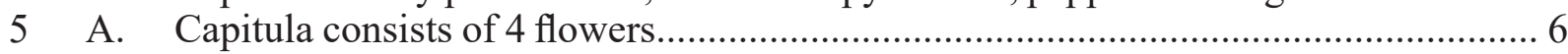

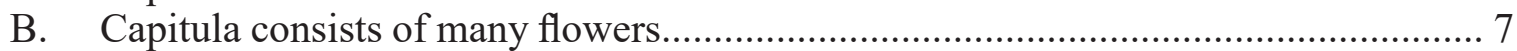

6 A. Leaves usually basal, rosulate, capitula fascicled on the apices of shoot.

Elephantopus

B. Leaves mostly cauline, alternate, capitula fascicled in racemose-spicate in the axil of small cauline leaves.

7 A. Capitula with foliaceous bracts at the base. Pseudelephantopus

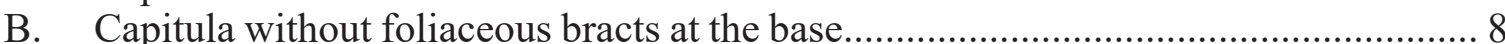

8 A. Anthers glandular.....

Vernonia

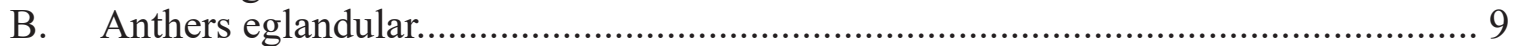

9 A. Involucral bracts 3-4-seriate, ovate, anthers without appendages, achenes obovoidterete, mostly 5-ribbed.

B. Involucral bracts 4-5-seriate, ovate to oblong, anthers with appendages, achenes oblong-obovoid, 5-10-ribbed..... Gymnanthemum

\section{A key to the additional cultivated species of Asteraceae from Java}

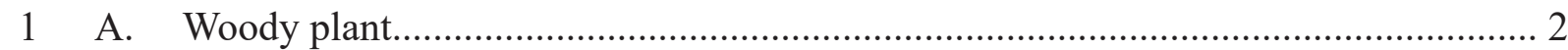

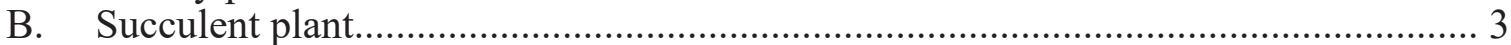

2 A. Shrub to small tree, branches whitish, petiole straight, lamina eliptic-lanceolate Gymnanthemum amygdalinum

B. Shrub, branches goldish brown, petiole curved, lamina oblong.... Tarlmounia elliptica

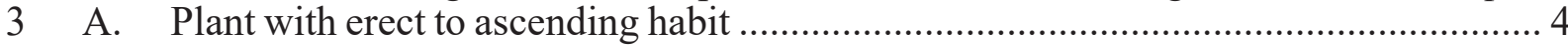

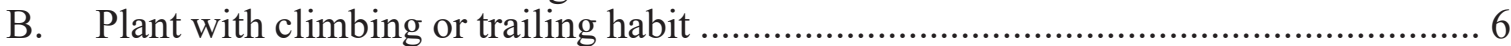

4 A. Leaves cylindric, whitish to grey, leaves apex acute.......................................... 5

B. Leaves spathulate, green to blueish green, leaves apex 3-5 lobed... Curio kleiniiformis

5 A. Leaves rosette, covered by arachnoid hairs, leaf width $<1 \mathrm{~cm}$............ Caputia scaposa

B. Leaves alternate, covered by tomentose hairs, leaf width $>1 \mathrm{~cm}$..... Caputia tomentosa

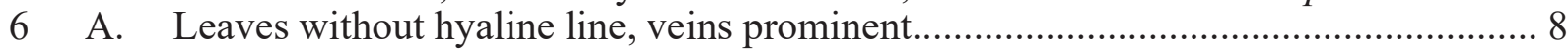

B. Leaves with hyaline line, veins inconspicuous.................................................... 7

7 A. Stem filiform, leaves globbose, green.................................................. Curio rowleyanus

B. Stem terete, leaves obovate, pale green or purplish............................. Kleinia petraea

8 A. Leaves hastate, inflorescence solitary, ray florets 8 on each head, pale yellow.

Senecio macroglossus

B. Leaves deltoid, inflorescence corymb, ray florets 5 on each head, bright yellow ..... Senecio tamoides 


\section{JURNAL BIDDJATI}

http://journal.uinsgd.ac.id/index.php/biodjati

Table 1. The Additional species of Asteraceae in Java

\begin{tabular}{|c|c|c|c|c|c|}
\hline No & Species & $\begin{array}{l}\text { Vernacular } \\
\text { name }\end{array}$ & Uses & Native range & $\begin{array}{l}\text { Location of field } \\
\text { survey }\end{array}$ \\
\hline 1. & $\begin{array}{l}\text { Caputia scaposa (DC.) } \\
\text { B. Nord. \& Pelser }\end{array}$ & Bunga senecio & 1 & $\begin{array}{l}\text { Southern Africa } \\
\text { (Nordenstam \& Pelser, } \\
\text { 2012). }\end{array}$ & $\begin{array}{l}\text { Langensari, } \\
\text { Lembang (Bdg) }\end{array}$ \\
\hline 2. & $\begin{array}{l}\text { C. tomentosa (Haw.) B. Nord. } \\
\text { \& Pelser }\end{array}$ & Bunga senecio & 1 & $\begin{array}{l}\text { Southern Africa } \\
\text { (Nordenstam \& Pelser, } \\
\text { 2012). }\end{array}$ & $\begin{array}{l}\text { Langensari, } \\
\text { Lembang (Bdg) }\end{array}$ \\
\hline 3. & $\begin{array}{l}\text { Curio kleiniiformis (Suess.) } \\
\text { L.V.Ozerova \& A.C.Timonin }\end{array}$ & Bunga senecio & 1 & Southern Africa & $\begin{array}{l}\text { Langensari, } \\
\text { Lembang (Bdg) }\end{array}$ \\
\hline 4. & $\begin{array}{l}\text { C. rowleyanus (H.Jacobsen) } \\
\text { P.V.Heath }\end{array}$ & Kaktus tasbih & 1 & $\begin{array}{l}\text { Southern Africa (Jacob- } \\
\text { sen, 1968). }\end{array}$ & Rancasari (Bdg) \\
\hline 5. & $\begin{array}{l}\text { Kleinia petraea (R.E. Fr.) } \\
\text { C. Jeffrey }\end{array}$ & Bunga senecio & 1 & $\begin{array}{l}\text { Kenya, Tanzania, and } \\
\text { Uganda (Jeffrey, 1986). }\end{array}$ & $\begin{array}{l}\text { Komp. PPR ITB, } \\
\text { Mekarwangi (Bdg) }\end{array}$ \\
\hline 6. & Senecio macroglossus DC. & Ivy daun tebal & 1 & $\begin{array}{l}\text { Southern Africa (Wood } \\
\text { \& Evans, 1912). }\end{array}$ & $\begin{array}{l}\text { Komp. PPR ITB, } \\
\text { Mekarwangi (Bdg) }\end{array}$ \\
\hline 7. & S. tamoides DC. & Bunga senecio & 1 & $\begin{array}{l}\text { Southern Africa (Wood } \\
\text { \& Evans, 1899). }\end{array}$ & $\begin{array}{l}\text { Komp. PPR ITB, } \\
\text { Mekarwangi (Bdg) }\end{array}$ \\
\hline 8. & $\begin{array}{l}\text { Gymnanthemum amygdali- } \\
\text { num (Delile) Walp. }\end{array}$ & $\begin{array}{l}\text { Daun afrika, } \\
\text { daun pahit, } \\
\text { daun insulin }\end{array}$ & 2,3 & $\begin{array}{l}\text { Tropical Africa } \\
\text { (Swelankomo et al., } \\
\text { 2016). }\end{array}$ & $\begin{array}{l}\text { IPB Dramaga (Bgr), } \\
\text { ITB Jatinangor } \\
\text { (Smd), Kopo Kat- } \\
\text { apang (Bdg), Pasir } \\
\text { Impun (Bdg) }\end{array}$ \\
\hline 9. & $\begin{array}{l}\text { Tarlmounia elliptica (DC.) H. } \\
\text { Rob. S. C. Keeley, Skvarla \& } \\
\text { R. Chan }\end{array}$ & $\begin{array}{l}\text { Tanaman Lee } \\
\text { Kwan Yew }\end{array}$ & 1,3 & $\begin{array}{l}\text { India, Myanmar, and } \\
\text { Thailand (Ghafoor, } \\
\text { 2015). }\end{array}$ & $\begin{array}{l}\text { Dramaga (Bgr); ITB } \\
\text { Bandung (Bdg), } \\
\text { ITB Jatinangor } \\
\text { (Smd) }\end{array}$ \\
\hline
\end{tabular}

Note: Bdg= Bandung; Bgr= Bogor; Smd=Sumedang; 1= ornamental plant; $2=$ medicinal plant; $3=$ hedge

Taxonomically, the nine newly recorded species were grouped into two tribes, i.e. Senecioneae and Vernonieae. The Senecioneae was characterized by a uniseriate involucre, pyrrolizidine alkaloids and the eremophilane, polyacetylenes-lacking, and ovules containing raphids (Funk et al., 2009). The additional members of Senecioneae in Java were Caputia scaposa, C. tomentosa, Curio kleiniiformis, C. rowleyanus, Kleinia petraea, Senecio macroglossus, and $S$. tamoides (Jacobsen, 1968; Nordenstam \& Pelser, 2012; Malenkova et al., 2014; Ozerova et al., 2017). These species were sold as ornamental plants in Bandung and Bogor (Figure 1). All of Irsyam \& Irwanto the species are native to Africa, particularly Southern Africa. Most of the Southern African Senecioneae are succulent plants that have morphological characteristics as adaptations to the semi-arid environment (Timonin et al., 2014).

Most of the observed plants did not flowering in the study period. However, they can still be distinguished by their vegetative characters. Both Senecio macroglossus and $S$. tamoides are climbers, but their leaves differ in shapes. Senecio macroglossus has hastate leaves, while the leaves of $S$. tamoides are deltoid. Morphologically, Curio rowleyanus and $K$. petraea are trailing herbs. They can 
Jurnal Biodjati 4(2):244-251, November 2019

\section{JURNAL BIDDJATI}

http://journal.uinsgd.ac.id/index.php/biodjati

be distinguished by the characteristic of their stem and leaf shapes. Curio rowleyanus has a filiform stem and globbose leaves, whereas $K$. petraea has terete stem and obovate leaves. Caputia scaposa and C. tomentosa are succulent species with cylindrical leaves. But the phyllotaxis and indumentum of both species show different patterns. Leaves of $C$. scaposa are arranged in rosette and covered by arachnoid hairs, whereas Caputia tomentosa has alternate leavesand is covered by tomentose hairs. Based on vegetative characters, the most easily recognized species is C. kleiniiformis.

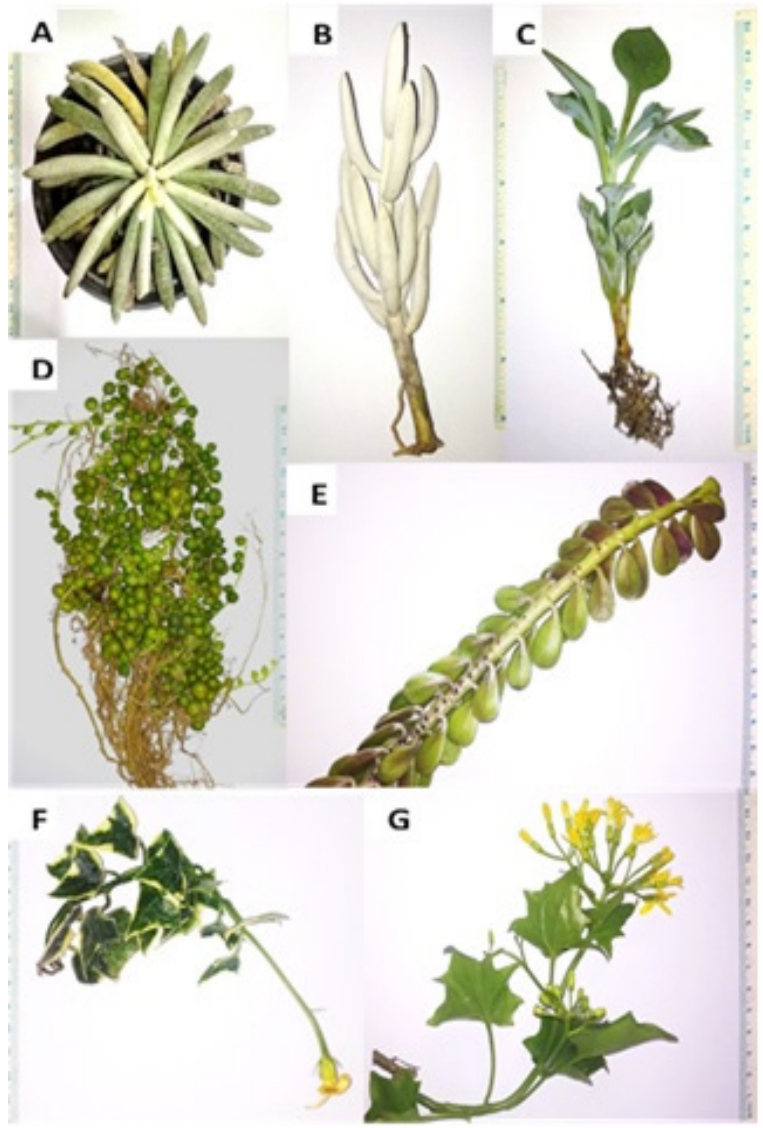

Figure 1. Additional species of Tribe Senecioneae in Java. (A) Caputia scaposa (DC.) B. Nord. \& Pelser, (B) Caputia tomentosa (Haw.) B. Nord. \& Pelser, (C) Curio kleiniiformis (Suess.) L. V.Ozerova \& A. C.Timonin, (D) Curio rowleyanus (H. Jacobsen) P. V.Heath, (E) Kleinia petraea (R. E. Fr.) C. Jeffrey, (F) Senecio macroglossus DC., (G) Senecio tamoides DC.

Jurnal Biodjati 4(2):244-251, November 2019
This species has spathulate leaves with blueish green color, and 3 to 5-lobed leaf apex.

The additional members of Vernonieae only consist of two species: Gymnanthemum amygdalinum and Tarlmounia elliptica (Figure 2). Morphologically, the tribe was characterized by alternate leaves with pinnate venation, T-shaped or stellate hairs, imbricate involucre, corollas blue to reddish or purple, slender tapering style branches and achenes usually with twin hairs (Robinson, 1999; Funk et al., 2009). The characters can be observed in G. amygdalinum and T. elliptica.

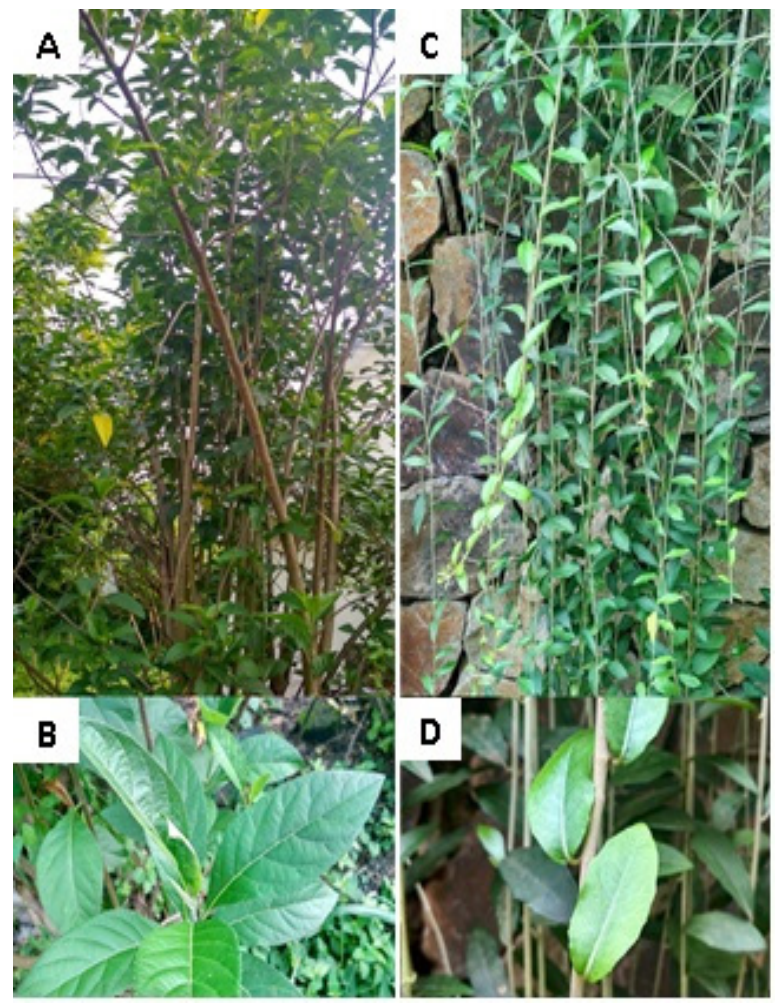

Figure 2. Additional species of Tribe Vernonieae in Java (A-B) Gymnanthemum amygdalinum (Delile) Walp., (C-D) Tarlmounia elliptica (DC.) H. Rob. S. C. Keeley, Skvarla \& R. Chan. 


\section{JURNAL BIDDJATI}

http://journal.uinsgd.ac.id/index.php/biodjati

Gymnanthemum amygdalinum is a synonym of Vernonia amygdalina Delile. It is native to Tropical Africa and became exotic in other tropical areas. The species is a shrub or small tree with elliptic to lanceolate lamina, straight petioles, and white or pinkish corollas. It was introduced to Java as a medicinal plant and also cultivated as a hedge in the gardens. Traditionally, leaf decoctions were used to treat diabetes and diarrhea. The wild populations of $G$. amygdalinum were discovered at several traditional gardens in Pasir Impun Subdistrict, Bandung. This species could be considered as naturalized species due to its ability to reproduce independently in the wild. Gymnanthemum amygdalinum produces a large number of seeds and it widely dispersed by wind. Furthermore, the species is also able to reproduce vegetatively by stem fragmentation. Other than Indonesia, G. amygdalinum was also introduced to India as medicinal plants and recorded as an additional species to the Flora of India in 2015 (Bhattacharjee et al., 2013; Swamy et al., 2015).

Tarlmounia elliptica is naturally distributed from India, Myanmar to Thailand (Ghafoor, 2015). The distribution outside of its native range have been reported in Taiwan in 1998 (Peng et al., 1998). Tarlmounia elliptica was occasionally cultivated as ornamental plants by Taiwanese people and it was naturalized in the southern part of the island (Peng et al., 1998). The species was also recently reported as naturalized species from O‘ahu, Hawaii (Imada, 2019). In Java, T. elliptica was commonly planted as a hanging plant for vertical gardens or natural barrier for house privacy due to its slender stems. However, the existence of T. elliptica in Java needs to be noticed, because of its potential to escape from cultivation and is naturalized in nature.
Nine additional cultivated species of Asteraceae were found from Bandung, Bogor, and Sumedang. These additional species were Caputia scaposa, C. tomentosa, Curio kleiniiformis, C. rowleyanus, Kleinia petraea, Senecio macroglossus, S. tamoides, Gymnanthemum amygdalinum and Tarlmounia elliptica. This study showed that the information on Asteraceae of Java needs to be revised. In the future, the accumulation of recent species discovery in Java will be needed to update the Flora of Java. It is also indicated that other additional species still occur in Java. Therefore, further research is required.

\section{ACKNOWLEDGMENTS}

The authors would like to thank Zakaria Al Anshori (Department of Silviculture, IPB) for helping us to explore and collect Gymnanthemum amygdalinum in Dramaga area, Bogor.

\section{REFERENCES}

Backer, C. A. \& Bakhuizen v/d Brink, R. C. Jr. (1965). Flora of Java. Volume II. Groningen, The Netherlands: Wolters-Noordhoff N. V.

Bhattacharjee, B., Lakshminarasimhan, P., Bhattacharjee, A., Agrawala, D. K. \& Pathak, M. K. (2013). Vernonia amygdalina Delile (Asteraceae) - An African medicinal plant introduced in India. Zoo's Print, 28(5), 18-20.

Funk, V. A, Susanna, A., Stuessy, T. \& Robinson, H. (2009). Classification of Compositae. In: Funk, V. A, Susanna, A., Stuessy, T. \& Bayer, R.J. Systematics, Evolution, and Biogeography of Compositae. Vienna: IAPT.

Ghafoor, A. (2015). Asteraceae: Trib. 3. Vernonieae. In: Wilson, A.J.G. Flora of Australia Volume 37-Asteraceae 1. 


\section{JURNAL BIDDJATI}

http://journal.uinsgd.ac.id/index.php/biodjati

Melbourne: Australian Biological Resources Study/CSIRO Publishing.

Imada, C. T. (2019). Hawaiian Naturalized Vascular Plants Checklist. Honolulu, Hawai'i: Bishop Museum.

Irsyam, A. S. D. \& Hariri, M. R. (2016). Eupatorium capillifolium (Lam.) Small ex Porter \& Britton (Asteraceae: Eupatorieae), Rekaman Baru untuk Flora Jawa. Jurnal Al-Kauniyah, 9(2), 80-86.

Jacobsen, H. (1968). String-of-Beads Senecio: Senecio rowleyanus Jacobs nov. spec. The National Cactus and Succulent Journal, 23(2), 30-31.

Jeffrey, C. (1986). The Senecioneae in East Tropical Africa: Notes on Compositae: IV. Kew Bulletin, 41(4), 873-943.

King, R. M. \& Robinson, H. (1970a). Studies in the Eupatorieae (Compositae) XIX. New Combinations in Ageratina. Phytologia, 19(4), 208-229.

King, R. M. \& Robinson, H. (1970b). Studies in the Eupatorieae (Compositae)---XXVI. A New Genus Austroeupatorium. Phytologia, 19(7), 433-435.

King, R. M. \& Robinson, H. (1970c). Studies in the Eupatorieae (Compositae)---XXIX. The Genus Chromolaena. Phytologia, 20(3), 196-209.

King, R. M. \& Robinson, H. (1970d). Studies in the Eupatorieae (Compositae). XXX. The Genus Ayapana. Phytologia, 20(3), 210-212.

King, R. M. \& Robinson, H. (1971). Studies in the Eupatorieae (Asteraceae)---LXI. Additions to the Hebeclinium Complex with Bartlettina, a New Generic Name. Phytologia, 22(3), 160-162.

Malenkova, E. D., Ozerova, L. V., Schanzer, I. A. \& Timonin, A. C. (2014). Re-considerations on Senecio oxyriifolius DC. and $S$. tropaeolifolius MacOwan ex F. Muell. (Asteraceae: Senecioneae).
Wulfenia, 21, 111-118.

Nordenstam, B. \& Pelser, P. B. (2012). Caputia, a New Genus to Accommodate Four Succulent South African Senecioneae (Compositae) Species. Compositae Newsletter, 50, 56-69.

Ozerova, L. V., Schanzer, I.A. \& Timonin, A.C. (2017). Curio Alliance (Asteraceae: Senecioneae) Revisited. Wulfenia, 24, 29-52.

Peng, C. I., Chung, K. F. \& Leu, W. P. (1998). Notes on Three Newly Naturalized Plants (Asteraceae) in Taiwan. Taiwania, 43(4), 320-329.

Robinson, H. (1999). Generic and Subtribal Classification of American Vernonieae. Smithsonian Contributions to Botany, 89, 1-116.

Rowley, G. (1967). Senecio haworthii in Bloom. The Cactus and Succulent Journal of Great Britain, 29(2), 37.

Rugayah, Retnowati, A., Windadri, F. I. \& Hidayat, A. (2004). Pengumpulan Data Taksonomi. In: Rugayah, Widjaja, E.A. \& Praptiwi. Pedoman Pengumpulan Data Keanekaragaman Flora. Bogor (ID): Puslit-LIPI.

Swamy, J., Prabhakar, G., Rasingam, L. \& Kamalakar, P. (2015). Gymnanthemum amygdalinum (Asteraceae)-A New Addition to the Flora of Peninsular India. International Journal of Advanced Research in Science and Technology, 4(7), 449-451.

Swelankomo, N., Manning, J. C. \& Magee, A. R. (2016). The Genus Gymnanthemum Cass. (Asteraceae: Vernonieae) in Southern Africa. South African Journal of Botany, 102, 81-101.

Timonin, A. C., Ozerova, L. V. \& Shantser, I. A. (2014). Evolution of Succulent Senecioneae (Asteraceae) of Southern Africa. Zhurnal obshcheú biologii, 75(1), 25-37. 


\section{JURNAL BI@DJATI}

http://journal.uinsgd.ac.id/index.php/biodjati

Tjitrosoedirdjo, S. S. \& Wahyuni, I. (2018). Rekor Baru Keberadaan Praxelis clematidea (Asteraceae) di Indonesia. Prosiding Seminar Nasional XX Himpunan Ilmu Gulma Indonesia: Resistensi Gulma terhadap Herbisida dan Dampaknya terhadap Lingkungan dan Produk Pertanian. Biotrop, 28 Nopember 2017. Hlm 212-217.

Wood, J. M. \& Evans, M. S. (1899). Natal plants: Descriptions and figures of Natal indigenous plants, with notes on their distribution, economic value, native names, etc. Volume 1. Durban: Bennett \& Davis.
Wood, J. M. \& Evans, M. S. (1912). Natal plants: Descriptions and figures of Natal indigenous plants, with notes on their distribution, economic value, native names, etc. Volume 6. Durban: Bennett \& Davis. 